\title{
Tailoring the Determinants of Implementation Behaviour Questionnaire (DIBQ) to best-practice low back pain primary care program implementation: a mixed-methods validity-testing in Sweden and Denmark
}

Inge Ris ( $\square$ iris@health.sdu.dk)

University Southern Denmark https://orcid.org/0000-0001-6623-4799

\section{Karin Schröder}

Linkopings universitet Medicinska Fakulteten

\section{Alice Kongsted}

Syddansk Universitet

\section{Allan Abbott \\ Linkopings universitet \\ Per Nilsen \\ Linkopings universitet \\ Jan Hartvigsen \\ Syddansk Universitet \\ Birgitta Öberg \\ Linkopings universitet}

\section{Research article}

Keywords: Determinants of Implementation Behaviour Questionnaire, Low Back Pain, Implementation, Primary Care, Theoretical Domains Framework

Posted Date: January 15th, 2020

DOI: https://doi.org/10.21203/rs.2.20919/v1

License: (9) This work is licensed under a Creative Commons Attribution 4.0 International License.

Read Full License 


\section{Abstract}

Background: Best-practice low back pain (LBP) primary care programs have been developed based on evidence-based clinical guidelines and are implemented in Sweden and Denmark. The Theoretical Domains Framework and its linkage to The Behavioural Change Wheel has been utilised in the design of the implementation object and its implementation strategy. Based on the Theoretical Domains Framework domains, the Determinants of Implementation Behaviour Questionnaire (DIBQ) has been developed to evaluate implementation determinants but its feasibility and validity needs to be tested and adapted to study specific contexts while maintaining its linkage to the Behavioural Change Wheel. The aim of this study was to tailor the DIBQ for evaluation of the implementation processes for best-practice LBP primary care programs in Sweden and Denmark. More specifically, the objectives were to i) Translate the DIBQ into Swedish and Danish, ii) Adapt the DIBQ into DIBQ-tailored (DIBQ-t) to study content validity, iii) Test the DIBQ-t for feasibility and iv) Perform initial validity testing of DIBQ-t.

Methods: A mixed methods design with a four-step process was used. First, forward translation of the DIBQ, then adaptation into DIBQ-t using qualitative face validity assessed by the project group followed by quantitative content validity assessment by an expert group. Finally, primary care clinicians completed the DIBQ-t directly after participation in a 2-day educational course prior to the implementation of the program to determine feasibility and construct validity using confirmatory factor analyses.

Results: In total 598 clinicians out of 609 responded, with only $2 \%$ of the items missing. The final DIBQ-t included 28 items describing 10 of the original 18 TDF domains and was considered feasible. The confirmatory factor analyses showed good fit after removing items 4 and 13 with the lowest domain loading. The DIBQ-t maintained linkage to all domains of the Capability-Opportunity-MotivationBehaviour model within the Behavioural Change Wheel. The clinicians' expectations according to the DIBQ-t indicate facilitating determinants outweighing barriers at the initiation of implementation processes.

Conclusions: The study resulted in a tailored version of the DIBQ, DIBQ-t, which is feasible and valid for evaluating clinicians' expectations regarding implementation determinants of best-practice LBP primary care programs.

\section{Background}

Evidence-based guidelines provide recommendations for clinical practice and have been developed in several countries to assist clinicians in managing patients presenting with low back pain (LBP) [1-3]. However, there is often a mismatch between recommendations and clinical practice [4-6] because barriers at the level of stakeholders such as patients, providers, organisations and health care systems can complicate the implementation of guidelines [7-10]. Although clinicians consider evidence-based guidelines important, they may not adopt and adhere to them in routine practice for several reasons [11]. Some clinicians consider guidelines as a threat to professional autonomy and inconsistency with clinical 
reasoning [12], or they may have beliefs and traditions that are not in line with the guideline recommendations $[12,13]$. Therefore, they may choose to rely upon experience and well-established habits using an intuitive, experiential approach $[12,14]$. In an effort to rectify these barriers of guideline implementation identified in previous literature, best-practice LBP primary care programs have been developed in Sweden and Denmark aiming to facilitate the adoption of guideline consistent care in the management of people seeking care for $\operatorname{LBP}[15,16]$.

The Theoretical Domains Framework (TDF) [17] and the Behavioural Change Wheel [18] are useful when developing implementation strategies. The TDF is a comprehensive behaviour change framework based on 128 constructs from 33 psychological theories categorized into 18 domains considered relevant to behaviours and cognitions involved in evidence-based practice implementation $[17,19]$. The TDF has also previously been linked to the Behavioural Change Wheel, which aids in interpreting how potential determinants of behavioural change could influence the effects of behavioural change interventions (i.e. the implementation strategy) on the central source of behaviour (i.e. use of a best- practice LBP primary care program) [20]. The Behavioural Change Wheel incorporates the Capability - Opportunity - Motivation Behaviour (COM-B) model [21] to describe the central source of behavior (Fig. 1).

Figure 1.

The TDF has also been utilised in the development of a survey instrument, the Determinants of Implementation Behaviour Questionnaire (DIBQ) [17, 19, 22], which quantitatively evaluates the 18 TDF domains role in implementation processes through 93 items. From these domains, researchers can identify the most relevant ones in relation to the aims and target population of a specific research and implementation context. However, feasibility and validity of tailoring the DIBQ to a specific context, here best-practice low back pain primary care program implementation, needs to be tested while maintaining its linkage to the Behavioural Change Wheel.

\section{Methods}

The aim of this study was thus to tailor the DIBQ for valid and feasible evaluation of the clinician expectations regarding implementation processes of best-practice LBP primary care programs in Sweden and Denmark. More specifically, the objectives were to i) Translate the DIBQ into Swedish and Danish, ii) Adapt the version into DIBQ tailored (DIBQ-t) to study best-practice low back pain primary care program implementation for content validity, iii) Test the DIBQ-t for feasibility and iv) Perform initial validity testing of DIBQ-t.

\section{Setting}

The BetterBackJ model of care in Sweden [15] and the GLA:D ® Back programme in Denmark [16] are best-practice programs for LBP in primary care. They have been developed in collaboration between researchers in the two countries to support the implementation of guideline consistent care. A comparable multifaceted implementation strategy, including a 2-days course with lectures, workshops 
and access to the supporting material, were used in both countries to enable clinicians to deliver the programs to patients with LBP.

\section{Design}

This study applies a mixed-method design in 4 phases. Translation of the DIBQ (phase 1); content validity assessment by an expert group (phase 2); adaptation into DIBQ-t and determining feasibility (phase 3); construct validity of DIBQ-t (phase 4) (Figure 2). The GRRAS [23] checklist (see Additional file 1) was used to guide our reporting of the study.

Figure 2.

\section{Phase 1 - Translation of Swedish and Danish version of DIBQ}

The translation of DIBQ into Swedish and Danish was based upon the English version of the questionnaire [22]. The original English version consists of 93 items assessing 18 domains [24]: Knowledge, skills, social/professional role, beliefs about capability, beliefs about consequences, optimism, intentions, goals, innovation, socio-political context, organisation, patients, innovation strategy, social influences, positive emotions, negative emotions, behavioural regulation and nature of behaviour. The English version has good construct validity, and most domains show high internal consistency reliability and discriminant validity [22]. The translation process was performed using the guidelines by Beaton [25]. Two people knowledgeable in English/Danish and English/Swedish, one with a clinical background and one with a native or academic knowledge for each language translated from English into Danish and Swedish. The translated versions were discussed by the authors to obtain consensus on the correct wording of the questions in Swedish and Danish languages. Subsequently, these versions were commented upon by linguistic (Swedish and Danish) experts to improve the readability of the translated questionnaire. Instead of backward translation, a panel of experts in musculoskeletal health and implementation research were used in the final stage of selecting questions [26]. They commented on the translation, wording, phrasing, and understandability.

\section{Phase 2 - Adaptation of the DIBQ into the DIBQ-tailored version and content validity assessment}

The process of tailoring the translated DIBQ into DIBQ-t involved selection of the most relevant of the original 18 domains and 93 items based on their suitability for evaluation of the implementation of BetterBack and GLA:D Back. First, qualitative content validity was tested by members of the project team (IR, AA, BÖ, and PN) representing both countries, by selecting domains of the original DIBQ for the DIBQ-t. The project team, consisting of two males, two females, representing musculoskeletal and implementation research and also a clinical background, aimed to include a realistic number of items to achieve a high response rate [27] while simultaneously covering evaluation of the implementation process at an individual, social, organisational and contextual level. Second, quantitative content validity was tested by experts with a professional or methodological research background in the musculoskeletal and/or implementation fields (Table 1). 
The experts were asked to rate each item of the DIBQ on a 1-4 Likert scale from 'not relevant' to 'very relevant' regarding evaluation of the implementation process of the best-practice LBP primary care programs in Sweden and Denmark. The ratings of the experts were indexed using Content Validity Index (CVI) [28]. An item was considered 'relevant' when scoring a CVI of 0.80 or more, i.e. $80 \%$ or more of the experts rated the questions 'relevant' or 'very relevant'. Inclusion of items in the DIBQ-t, was based upon three criteria: 1) Swedish and Danish project leaders selected the items related to domains relevant to the project, and experts rated the item with a $\mathrm{CVI} \geq 0.80$, or 2) an expert rated relevance score with a CVI = 1.00 , regardless of the item being selected by the project leaders, and 3) the project leaders of each country added items included by the project team and with $80 \% \mathrm{CVI}$ of either the Swedish or Danish experts to anticipate differences in contexts between the countries. The main differences in contexts were that Danish clinicians to a larger degree worked in private clinics and chose to self-fund their participation in the best-practice LBP primary care program. The Swedish clinicians worked in public clinics, and the decision to participate was made by their clinic managers and participation was mandatory and without costs for the participants. The project team considered it of importance that DIBQ-t content validity be relevant for both private and public health care system settings.

\section{Phase 3 and 4 - Feasibility and Construct validity}

All clinicians from public physiotherapy clinics in the Östergötland health care region in Sweden $(n=110)$ involved in a Hybrid type 2 implementation-cluster randomised effectiveness trial (BetterBackJ ClinicalTrials.gov NCT03147300) [15] and clinicians from private primary care clinics (physiotherapists and chiropractors) in Denmark ( $n=488$ ) involved in a Hybrid type 3 implementation-observational clinical intervention cohort (GLA:D Back) $[16,29]$ were asked to complete the DIBQ-t after a 2-day educational course. During the course, the clinicians were trained in delivering the programs to patients through lectures and workshops [15]. The items (statements about implementation) in DIBQ-t were scored on a 5point Likert Scale anchored 'strongly agree', agree', 'neither agree nor disagree', 'disagree', and 'strongly disagree' and for items 5-9 similarly anchored 'very easy', 'easy', 'neither easy nor difficult', 'difficult', and 'very difficult'. Answers for the DIBQ-t were obtained directly after course participation, thereby representing the expectations of the implementation of the programs shortly after the clinicians had gained detailed theoretical knowledge about the content and execution of the program but had not yet delivered it in practice. Data were collected via a digital platform in Denmark (OPEN REDCap, Vanderbilt University) via a link to the questionnaire emailed to the participants within 24 hours after they had attended a course in 2018. In Sweden, the data was collected using paper-based questionnaires completed immediately upon finishing the course in the period 27th of March 2017 to 30th of January 2018.

\section{Data analyses}

Descriptive statistics were used to present qualitative content validity results by the project group, as well as the results of the quantitative content validity testing using CVI scores. 
The joint data from the Swedish and Danish clinicians on the DIBQ-t was tested for feasibility, missing data, and construct validity, the latter using a confirmatory factor analysis. Domain and item-level data of the DIBQ-t were analysed as categorical data based upon the results of the 5-point Likert scale. The proportion of clinicians responding 'agree' or 'strongly agree' to each domain, as well as the results for the items in each domain is reported. Ratings of 'agree' or 'strongly agree' indicate that the domain is a facilitating determinant of implementation behaviour, whereas 'disagree' or 'strongly disagree' indicate that the domain is a hindering determinant of implementation behaviour. Data was analysed for missing data and reported descriptively with the proportion of missing data used to judge feasibility.

A confirmatory factor analysis [30] assessed the internal construct validity using the Laavan package in the $\mathrm{R}$ version 3.5.1. Cut off values according to current recommendations reported by Perry et al [31] were applied. Root mean square of approximation (RMSEA), root mean square residual (SRMR) (both with cutoff < 0.05), comparative fit index (CFI) and Tucker-Lewis Index (TLI) (both with cut-off score > 0.9) were used to evaluate the model-fit. Adequate estimates of loading of the items on the domains was defined at 0.4 or more [32].

\section{Results}

\section{Phase 1 - Translation of DIBQ in Swedish and Danish}

The Swedish and Danish versions of the DIBQ are presented in Appendix 1 and Appendix 2. There were no important disagreements between the translators. Experts' comments on the translation were incorporated into the questionnaire. Comments involved specific phrasing (questions $2,18,86$ ) that could be misunderstood by respondents and concerned questions that were phrased as if the response options were 'yes/no' instead of rated on a Likert-scale (questions 34,65 ).

\section{Phase 2 - Adaptation of the DIBQ into the DIBQ-tailored version and content validity assessment.}

The project team selected 53 items in 10 domains. The selection of items from the DIBQ to DIBQ-t by the project team and experts is described in Table 2.

A total of 28 items in the final Swedish/Danish version of the DIBQ, DIBQ-t were considered feasible to evaluate the implementation process of the programmes. Eighteen items were included as they met criteria 1: selected by the project leaders plus having $80 \%$ or $100 \%$ CVI of both Danish and Swedish experts. Additional 10 items were included, based upon criteria 3: being selected by the project leaders and had $80 \%$ or $100 \%$ CVI by either the Danish (DIBQ-t question $8,9,21,23,24$ ) or Swedish (DIBQ-t question $13,14,20,27,28$ ) experts, anticipating the differences in context for the countries. No item met the criteria 2 (expert rated relevance score with a $C V I=1.00$, regardless of the item being selected by the project leaders).

Table 2 
DIBQ-t covers 10 out of 18 TDF domains: Knowledge, Skills, Beliefs about Capabilities, Beliefs about Consequences, Intentions, Innovation, Organisation, Patients, Social influences, Behavioural regulation. The items and related domains included in DIBQ-t are described in detail in Table 3.

Table 3

The DIBQ-t maintains linked to all domains of the Capability - Opportunity - Motivation - Behaviour (COM-B) model within the Behavioural Change Wheel, which is reported in Table 4.

Table 4

\section{Phase 3 - Feasibility of the DIBQ-t Sweden, Denmark combined}

From 609 invited clinicians, 598 (98\%) answered the DIBQ-t, 110 in Sweden and 488 in Denmark including 368 men and 226 women. Mean age was 39 years (SD 11; range 22 to 70 ). Almost $33 \%$ had less than 6 years' experience and $20 \%$ over 20 years. Of a total of 16,744 possible answers (598 participants answering 28 questions), 39 were missing (2\%).

In general, responses to most domain items indicated positive expectations to implement the program (Figure 3). The domains with the highest frequency of agreed or strongly agreed item responses was 'Skills' (94\%) and the lowest frequency of agreed or strongly agreed item responses was 'Behavioural Regulation' (55\%).

Figure 3.

Analysing each item independently provided a more detailed presentation of the results (Figure 4). In 21 items, $75 \%$ of clinicians scored 'agree' or 'agree strongly'. In seven items, $25 \%$ or more clinicians scored 'neither, nor': item 13 - recognition from work (52\%), item 28 - planning of the program when patients are not motivated (47\%), item 23 and 24 - opinions and support from colleagues (46\%, 37\%), item 26, 27 planning how and when to deliver the program $(25 \%, 28 \%)$ and item 16 - adapt the program to clinician's need (25\%). Items with highest score on 'disagree' were item 27 and 28 (10\% and $14 \%$ of clinicians) both related to planning the delivery of the program.

Figure 4.

\section{Phase 4 - Construct validity, confirmatory factor analysis}

The initial assessment of construct validity included 28 items, however this model did not reach the predefined cut-off values for model fit. Based on domains with most items and their items with the lowest domain loadings and lowest content validity, items were sequentially removed to attain adequate model fit. As a result, Item 4 ('I am confident that I can deliver Better Back/GLA:D Back) and 13 ('I expect that, when I deliver Better Back/GLA:D Back, I get recognition from the work context') were removed to obtain an adequate fit of the model. Further removal of 2 more items (item 25: '/ can count on support from professionals with whom I deliver Better Back/GLA:D Back when things get tough around delivering Better 
Back/GLA:D Back, and 28: 'I have a clear plan with regard to delivering Better Back/GLA:D Back when participants are not motivated) did not strengthen the model further. The final analyses are therefore reported for 26 items (Table 5).

\section{Table 5}

The estimated factor loadings of the items in relation to the domains are between 0.365 and 0.819 where 3 items (items 12, 15 and 16) were below 0.4, but all items had p-values $<0.001$.

The correlation between the domains are between 0.11 (patient and intention) and 0.74 (innovation and consequences) (Table 6), therefore not highly correlated, suggesting the domains are separated domains [33].

Table 6

\section{Discussion}

\section{Key findings}

DIBQ-t is a feasible and valid version of the DIBQ developed to evaluate the expectations of the implementation process regarding best-practice LBP primary care programs. The DIBQ-t includes 28 items, representing 10 of the initially suggested 18 domains in the TDF framework. The included TDF domains, and their linkage to the COM-B model within the Behavioural Change Wheel were: 'Skills', 'Knowledge', 'Behavioural Regulation', and 'Innovation' (Capability), 'Social Influences', 'Patients', and 'Organisation' (Opportunity), and 'Beliefs of Capabilities', 'Beliefs of Consequences', and 'Intentions' (Motivation).

The piloting of the DIBQ-t in the Swedish and Danish primary care context demonstrated the initial implementation strategy has resulted in a positive facilitation of clinicians' expectations regarding all TDF related determinants of best-practice LBP primary care program implementation. In other words, clinicians expected no determinants to hinder the initiation of implementation processes. This suggests that sustainability aspects of the implementation strategy should continue to aim at facilitating all determinants longitudinally. This will be investigated in a future step, allowing evaluation of the construct validity of the DIBQ-t in a longitudinal data collection on this cohort. The response rate of the DIBQ was high, with only $2 \%$ missing data demonstrating its feasible use.

\section{Translation DIBQ and tailoring into DIBQ-t}

The process of translation of DIBQ involved expert opinions on the questionnaire but did not include a backward translation. However, robust evidence is lacking for the need and value of backward translation $[34,35]$. Epstein et al studied different translation methods and concluded that the inclusion of an expert panel improved the quality of the instrument, especially the face validity and content validity. This means 
that backward translation is not necessary when the expert panel is skilled in the original language [26]. In this study, this criterion was fulfilled as all experts use English regularly both spoken and written.

The tailoring of the DIBQ into DIBQ-t was done at two levels. Both the project team and the expert panel selected relevant questions of the original DIBQ to evaluate the implementation process of a best-practice LBP primary care program. This approach reduced the risk of either overlooking relevant items or adding superfluous items. Some questions were added to the DIBQ-t, even though the inclusion criteria (selected by project leaders plus CVI $80 \%$ by experts) were met with only the Danish or Swedish experts. This selection enabled comparison of different contexts and cultures. The implementation process in Denmark has mainly taken place in private health clinics whereas implementation in Sweden has occurred in public health clinics. The course in Denmark had a fee for the participants, and participants must actively signup for the course. In contrast, the Swedish course was free of charge and participants were enrolled automatically. This difference between the countries may impose different financial and motivational aspects on the implementation process, which were important to account for in the DIBQ-t.

\section{Interpreting the DIBQ-t through linkage to COM-B within the Behavioural Change Wheel}

Within the Capability category of the COM-B model, the TDF domain 'Behavioural Regulation' had the lowest frequency of 'agree' or 'strongly agree' item responses, whereas the TDF domains 'Knowledge' and 'Skills' had over $90 \%$ of clinicians that strongly agreed or agreed with the items. This suggests that even though the clinicians expect to be capable by having the skills and knowledge to implement, they are less certain on a clear plan on how to operate the program. When analysing the 'behavioural regulation' TDF domain on an item-level, planning management of unmotivated patients had a low expectancy by the clinicians. This highlights the importance to include tools for patient motivation in implementation sustainability strategies.

Regarding the COM-B category of Opportunity, in the TDF domain 'Social Influences' the item 23 'influences of important others' had lowest frequency of 'agree' or 'strongly agree' responses. One can therefore consider that providing opportunity for positive influence of important others such as clinical champions is an important aspect to include in implementation sustainability strategies to improve their facilitation longitudinally.

Regarding the COM-B category Motivation, overall, TDF domains had over $80 \%$ scoring 'agree' or 'strongly agree'. This implies that, overall, clinicians' intentions, beliefs of capabilities and beliefs of consequences towards implementing the programs were perceived as a highly facilitative for implementation of the best-practice LBP primary care program. However, the TDF domain 'beliefs of consequences', item 13: 'to receive recognition from the work context' had the lowest frequency (40\%) of 'agree' or 'strongly agree' responses. This may imply that recognition from work does not have a high importance for motivation the implement the program.

\section{Strengths and limitations}


This study was conducted in two different countries with different contexts. The total item-bank of DIBQ-t therefore covers a wide spectrum to evaluate implementation processes generalisable to private and public LBP primary care internationally.

This current study focuses on clinicians' expectations on best-practice LBP primary care program implementation and confirms a stable construct of the DIBQ-t for monitoring barrier and facilitator qualities of the determinants. Considering that the construct validity applies to the clinicians' expectations of the implementation process, further analyses are planned after a longitudinal period of volition. Also, studies on changes in different TDF domains over time and their potential mediational role on clinician confidence, beliefs and intervention behaviour will be performed.

\section{Conclusions}

DIBQ was tailored for use in the evaluation of implementation of best-practice low back pain primary care programs resulting in an English, Swedish and Danish version, the DIBQ-t. The DIBQ-t was feasible to use and had adequate content and construct validity. The clinicians' expectations to implementation according to the DIBQ-t indicate facilitating determinants outweighing barriers for implementation of LBP programs in Sweden and Denmark. There is a need for further testing of DIBQ-t after the volition phase of the implementation object and for evaluating to what extent high expectations on the DIBQ-t is reflected in a high degree on implementation.

\section{Abbreviations}

LBP

low back pain

TDF

Theoretical Domains Framework

COM-B

Capability - Opportunity - Motivation - Behaviour

DIBQ

Determinants of Implementation Behaviour Questionnaire

DIBQ-t

DIBQ tailored to study best-practice low back pain primary care program implementation

\section{Declarations}

Ethics approval and consent to participate: Ethical clearance in Sweden for the study (Dnr: 2017-35/31) has been attained through the Regional Ethics Committee in Linköping. After obtaining a written and verbal explanatory statement regarding participation in the study, participants provided implied consent by returning a completed questionnaire for the study. The Regional Committees on Health Research Ethics for Southern Denmark decided that the study did not need ethical approval (file number S- 
20172000-93). The Danish data collection has obtained authorisation from the Danish Data Protection Agency (DPA) as part of the University of Southern Denmark's institutional authorisation (DPA no. 201557-0008 SDU no. 17/30591). According to Danish regulations, an observational study implementing a nonexperimental treatment that was offered to patients on the decision of the clinicians does not undergo research ethics evaluation (The National Committee on Health Research Ethics. Act on Research Ethics Review of Health Research Projects 2019 (updated 2019-02-21), accessed 02-12-2019). Digital informed consent was obtained from the Danish participants when they signed up online for the course, following normal procedures of the Danish Data Protection Agency for the collection of non-sensitive personal data. At signing up for the course the clinicians have explicitly consented to the terms of participation, among these the transmission of relevant personal data for project use.

Consent for publication: not applicable

Availability of data and material: The datasets used and/or analysed during the current study are available from the corresponding author on reasonable request.

Competing interests: AK's position at the University of Southern Denmark is financially supported by the Foundation for Chiropractic Research and Postgraduate Education, and IR's position is supported by income from the GLA:D Back clinician courses. GLA:D® is a non-profit initiative hosted at the University of Southern Denmark and the GLA:D® trademark is property of the University of Southern Denmark. The GLA:D initiative is developed in close collaboration with the SDU Research \& Innovation Organisation, including legal reviews. The researchers do not have any personal financial benefits from working with the project.

Funding: The study did not receive external funding in Denmark. The Research Council in Southeast Sweden (grant number FORSS*660371) and the Swedish Research Council (grant number 2017*01444) supported the salaries of Allan Abbott, Karin Schröder, and Birgitta Öberg. The funding source did not play a role in the design of the study or collection, analysis, and interpretation of the data or in writing the manuscript.

Authors' contributions: IR, AK, BÖ, KS, AA, JH, and PN were involved in the design of the study. IR, AK, BÖ, $K S$, AA were involved in data collection and are responsible for data analyses. IR, AK, BÖ, KS, AA, JH, and $\mathrm{PN}$ were involved in the development of the manuscript and have approved the final manuscript.

Acknowledgements: We would like to acknowledge the Odense Patient data Explorative Network (OPEN) for access to REDCap for support with the electronic data collection, Henrik Hedevik, statistician in Linköping, for doing the confirmatory factor analyses, and the involved experts and clinicians for using resources to provide data to the study.

\section{References}


1. Sundhedsstyrelsen: National klinisk retningslinje for behandling af nyopståede lænderygsmerter. Edited by Sundhedsstyrelsen. Copenhagen; 2016.

2. Sundhedsstyrelsen: National klinisk retningslinje for ikke-kirurgisk behandling af nylig opstået lumbal nerverodspåvirkning (lumbal radikulopati). Edited by Sundhedsstyrelsen. Copenhagen; 2016.

3. Savigny P, Watson P, Underwood M, Guideline Development G: Early management of persistent nonspecific low back pain: summary of NICE guidance. BMJ 2009, 338:b1805.

4. Bernhardsson S, Oberg B, Johansson K, Nilsen P, Larsson ME: Clinical practice in line with evidence? A survey among primary care physiotherapists in western Sweden. J Eval Clin Pract 2015, 21(6):1169-1177.

5. Grol R, Grimshaw J: From best evidence to best practice: effective implementation of change in patients' care. Lancet 2003, 362(9391):1225-1230.

6. Grimshaw JM, Eccles MP: Is evidence-based implementation of evidence-based care possible? Med J Aust 2004, 180(6 Suppl):S50-51.

7. Flottorp SA, Oxman AD, Krause J, Musila NR, Wensing M, Godycki-Cwirko M, Baker R, Eccles MP: A checklist for identifying determinants of practice: a systematic review and synthesis of frameworks and taxonomies of factors that prevent or enable improvements in healthcare professional practice. Implement Sci.2013, 8:35.

8. Grimshaw JM, Thomas RE, MacLennan G, Fraser C, Ramsay CR, Vale L, Whitty P, Eccles MP, Matowe $\mathrm{L}$, Shirran $\mathrm{L}$ et al: Effectiveness and efficiency of guideline dissemination and implementation strategies. Health Technol Assess 2004, 8(6):iii-iv, 1-72.

9. Grol R: Successes and failures in the implementation of evidence-based guidelines for clinical practice. Med Care 2001, 39(8 Suppl 2):li46-54.

10. Sheldon TA, Cullum N, Dawson D, Lankshear A, Lowson K, Watt I: What's the evidence that NICE guidance has been implemented? Results from a national evaluation using time series analysis, audit of patients' notes, and interviews. Br Med J 2004, 329.

11. Bernhardsson S, Johansson K, Nilsen P, Oberg B, Larsson ME: Determinants of guideline use in primary care physical therapy: a cross-sectional survey of attitudes, knowledge, and behavior. Phys. Ther. 2014, 94(3):343-354.

12. Slade SC, Kent P, Patel S, Bucknall T, Buchbinder R: Barriers to Primary Care Clinician Adherence to Clinical Guidelines for the Management of Low Back Pain: A Systematic Review and Metasynthesis of Qualitative Studies. Clin J Pain 2016, 32(9):800-816.

13. Di lorio D, Henley E, Doughty A: A survey of primary care physician practice patterns and adherence to acute low back problem guidelines. Arch Fam Med 2000, 9(10):1015-1021.

14. Langridge N, Roberts $L$, Pope $C$ : The clinical reasoning processes of extended scope physiotherapists assessing patients with low back pain. Man Ther 2015, 20(6):745-750.

15. Abbott A, Schroder K, Enthoven P, Nilsen P, Oberg B: Effectiveness of implementing a best practice primary healthcare model for low back pain (BetterBack) compared with current routine care in the 
Swedish context: an internal pilot study informed protocol for an effectiveness-implementation hybrid type 2 trial. BMJ Open 2018, 8(4):e019906.

16. Kjaer P, Kongsted A, Ris I, Abbott A, Rasmussen CDN, Roos EM, Skou ST, Andersen TE, Hartvigsen J: GLA:D((R)) Back group-based patient education integrated with exercises to support selfmanagement of back pain - development, theories and scientific evidence. BMC Musculoskelet Disord 2018, 19(1):418.

17. Michie S, Johnston M, Abraham C, Lawton R, Parker D, Walker A: Making psychological theory useful for implementing evidence based practice: a consensus approach. Qual Saf Health Care 2005, 14(1):26-33.

18. Amemori M, Michie S, Korhonen T, Murtomaa $\mathrm{H}$, Kinnunen $\mathrm{TH}$ : Assessing implementation difficulties in tobacco use prevention and cessation counselling among dental providers. Implement Sci:2011, 6.

19. Cane J, O'Connor D, Michie S: Validation of the theoretical domains framework for use in behaviour change and implementation research. Implement Sci.2012, 7:37.

20. Bala, H., et al. (2016). "If the Worst Happens: Five Strategies for Developing and Leveraging Information Technology-Enabled Disaster Response in Healthcare." IEEE J Biomed Health Inform 20(6): 1545-1551.

21. Michie S, van Stralen MM, West R: The behaviour change wheel: a new method for characterising and designing behaviour change interventions. Implement Sci.2011, 6:42.

22. Huijg JM, Gebhardt WA, Dusseldorp E, Verheijden MW, van der Zouwe N, Middelkoop BJ, Crone MR: Measuring determinants of implementation behavior: psychometric properties of a questionnaire based on the theoretical domains framework. Implement Sci: 2014, 9:33.

23. Kottner J, Audige L, Brorson S, Donner A, Gajewski BJ, Hrobjartsson A, Roberts C, Shoukri M, Streiner DL: Guidelines for Reporting Reliability and Agreement Studies (GRRAS) were proposed. J. Clin. Epidemiol 2011, 64(1):96-106.

24. Atkins L, Francis J, Islam R, O'Connor D, Patey A, Ivers N, Foy R, Duncan EM, Colquhoun H, Grimshaw $\mathrm{JM}$ et al: A guide to using the Theoretical Domains Framework of behaviour change to investigate implementation problems. Implement Sci: 2017, 12(1):77.

25. Beaton DE, Bombardier C, Guillemin F, Ferraz MB: Guidelines for the process of cross-cultural adaptation of self-report measures. Spine 2000, 25(24):3186-3191.

26. Epstein J, Osborne RH, Elsworth GR, Beaton DE, Guillemin F: Cross-cultural adaptation of the Health Education Impact Questionnaire: experimental study showed expert committee, not back-translation, added value. J. Clin. Epidemiol 2015, 68(4):360-369.

27. Edwards PJ, Roberts I, Clarke MJ, Diguiseppi C, Wentz R, Kwan I, Cooper R, Felix LM, Pratap S: Methods to increase response to postal and electronic questionnaires. Cochrane Database Syst. Rev 2009(3):Mr000008.

28. Polit DF, Beck CT: The content validity index: are you sure you know what's being reported? Critique and recommendations. Res Nurs Health 2006, 29(5):489-497. 
29. Kongsted A, Ris I, Kjaer P, Vach W, Mors $\emptyset$ L, Hartvigsen J: GLA:D® Back: implementation of groupbased patient education integrated with exercises to support self-management of back pain protocol for a hybrid effectiveness-implementation study. BMC Musculoskelet Disord 2019, 20(1):85.

30. Brown TA: Confirmatory Factor Analysis for Applied Research. London: The Guilford Press 2006.

31. Perry JL, Nicholls AR, Clough PJ, Crust L: Assessing Model Fit: Caveats and Recommendations for Confirmatory Factor Analysis and Exploratory Structural Equation Modeling. Meas Phys Educ Exerc Sci 2015, 19(1):12-21.

32. Stevens J: Applied multivariate statistics for the social sciences (2nd edition): Lawrence Erlbaum; 1992.

33. Tabachnick BF, Fidell LS: Using multivariate statistics, 6 edn; Pearson 2013.

34. da Mota Falcao D, Ciconelli RM, Ferraz MB: Translation and cultural adaptation of quality of life questionnaires: an evaluation of methodology. J Rheumato/ 2003, 30(2):379-385.

35. Perneger TV, Leplège A, Etter J-F: Cross-Cultural Adaptation of a Psychometric Instrument. J Clin Epidemiol, 52(11):1037-1046.

\section{Tables}

Table 1. Demographics Experts panel

\begin{tabular}{lccc}
\hline \multicolumn{1}{c}{ Variables } & Sweden & Denmark & Total \\
\hline male / female & $1 / 6$ & $3 / 6$ & $4 / 12$ \\
physiotherapist /chiropractor/other & $3 / 0 / 4$ & $4 / 5 / 0$ & $7 / 5 / 4$ \\
\hline age: mean (SD) & $55.4(7.6)$ & $44.9(11.5)$ & $49.5(11.1)$ \\
\hline years clinical experience: mean (SD) & $14.7(10.6)$ & $15.6(12.5)$ & $15.2(11.3)$ \\
\hline years research experience: mean (SD) & $12.1(6.3)$ & $8.8(7.6)$ & $10.3(7.1)$ \\
\hline
\end{tabular}

$\mathrm{SD}=$ Standard Deviation 
Table 2. Selection of DIBQ domains/items to DIBQ-LBP by project team, and Swedish and Danish experts

\begin{tabular}{|c|c|c|c|c|c|c|c|}
\hline Domains & Items & $\begin{array}{c}\text { Selected } \\
\text { by } \\
\text { project } \\
\text { team }\end{array}$ & $\begin{array}{c}\text { Danish } \\
\text { experts } \\
(n=c V l \\
80 \%)\end{array}$ & $\begin{array}{c}\text { Swedish } \\
\text { experts } \\
(n=C V I \\
80 \%)\end{array}$ & $\begin{array}{l}\text { Danish } \\
\text { experts } \\
(n=C V I \\
100 \%)\end{array}$ & $\begin{array}{c}\begin{array}{c}\text { Swedish } \\
\text { experts } \\
(n=C V I \\
100 \%)\end{array}\end{array}$ & $\begin{array}{l}\text { Selected } \\
\text { in } \\
\text { SWE/DK, } \\
\text { only } \\
\text { SWE or } \\
\text { DK }\end{array}$ \\
\hline
\end{tabular}

1. Knowledge 1.I know how to deliver Better Back/GLA:D Back following the programme.

$\mathrm{X}$

$\mathrm{X}$

$\mathrm{X}$

x SWE/DK

2. Objectives of Better Back/GLA:D Back and my role in this are clearly defined for me.

$\mathrm{x}$

$x$

$\mathrm{x}$

SWE/DK

3. With regard to Better Back/GLA:D Back, I know what my

$\mathrm{x}$

$\mathrm{x}$

SWE responsibilities are.

4. In my work with Better Back/GLA:D Back, I know exactly

$\mathrm{x}$

$\mathrm{x}$

SWE what is expected from me.

2. Skills 5. I have been trained in delivering Better Back/GLA:D Back following the programme.

$\mathrm{x}$

SWE

6. I have the skills to deliver Better Back/GLA:D Back

$x$

$x$

$x$

$\mathrm{x}$

$x \quad$ SWE/DK

following the programme. 
9. As a PT, it is my job to deliver Better Back/GLA:D Back following the programme.

10. It is my responsibility as a PT to deliver Better Back/GLA:D Back following the programme.

$\begin{array}{lllll}\begin{array}{l}\text { 4. Beliefs } \\ \text { about }\end{array} & \begin{array}{l}\text { 11. I am confident that I can deliver Better Back/GLA:D Back } \\ \text { following the programme. }\end{array} & \text { x } & \text { x } & \text { SWE/DK } \\ \begin{array}{l}\text { 12. I am confident that I can deliver Better Back/GLA:D Back } \\ \text { following the programme even when other professionals } \\ \text { with whom I deliver Better Back/GLA:D Back do not do this. }\end{array} & \text { x } & \text { SWE } \\ & & \end{array}$

13. I am confident that I can deliver Better Back/GLA:D Back $\quad \mathrm{x}$ following the programme even when there is little time.

14. I am confident that I can deliver Better Back/GLA:D Back $\quad x$ following the programme even when participants are not motivated. 
16. For me, delivering Better Back/GLA:D Back following the

X

$\mathrm{x}$

$\mathrm{X}$

x SWE/DK

programme is (very difficult - very easy).

17. For me, performing the intake is (very difficult - very

$x$

$\mathrm{x}$

$\mathrm{X}$

SWE/DK easy).

18. For me, delivering the training program is (very difficult - very easy).

x

X

X

SWE/DK

19. For me, performing the evaluation is (very difficult very easy).

$\mathrm{X}$

20. For me, giving attention to participant's maintenance of $\mathrm{x}$ physical activity behavior outside Better Back/GLA:D Back is (very difficult - very easy).

21. For me, reporting about the Better Back/GLA:D Back to

$\mathrm{X}$

$\mathrm{X}$

SWE/DK the referring professional is (very difficult - very easy). 
23. In my work as a PT, I'm always optimistic about the future.

24. In my work as a PT, overall, I expect more good things to happen than bad.

\begin{tabular}{llllll}
\hline $\begin{array}{l}\text { 6. Beliefs } \\
\text { about }\end{array}$ & 25. For me, delivering Better Back/GLA:D Back following the & programme is (not useful at all - very useful). & x & x & SWE/DK \\
consequences & & & &
\end{tabular}

26. For me, delivering Better Back/GLA:D Back following the $\quad x$ programme is (not worthwhile at all - very worthwhile).

27. For me, delivering Better Back/GLA:D Back following the programme is (not pleasurable at all - very pleasurable).

28. For me, delivering Better Back/GLA:D Back following the programme is (not interesting at all - very interesting). 
29. If I deliver Better Back/GLA:D Back following the this will strengthen the collaboration with professionals with whom I deliver Better Back/GLA:D Back.

32. If I deliver Better Back/GLA:D Back following the Programme, I will feel satisfied. 
34. When I deliver Better Back/GLA:D Back following the

programme, I get financial reimbursement.

35. When I deliver Better Back/GLA:D Back following the

$\mathrm{X}$

$\mathrm{x}$

x SWE/DK

programme, I get recognition from the work context.

36. When I deliver Better Back/GLA:D Back following the

$\mathrm{X}$

programme, I get recognition from participants.

7. Intentions 37. I intend to deliver Better Back/GLA:D Back following the programme in the next three months.

$x$

$x$

$\mathrm{x}$

SWE/DK

38. I will definitely deliver Better Back/GLA:D Back following

$x$ the programme in the next three months.

39. How strong is your intention to deliver Better

$\mathrm{x}$

$\mathrm{x}$ Back/GLA:D Back following the programme in the next three months? 
agenda a higher priority than delivering Better Back/GLA:D

Back following the programme?

41. How often is working on something else on your agenda more urgent than delivering Better Back/GLA:D Back following the programme?

9. Innovation 42. It is possible to tailor Better Back/GLA:D Back to participants' needs.

$\begin{array}{llllll}x & x & x & x & \text { SWE/DK }\end{array}$

43. It is possible to tailor Better Back/GLA:D Back to professionals' needs.

$\mathrm{x}$

$\mathrm{x}$

$\mathrm{x}$

x SWE/DK

44. Better Back/GLA:D Back costs little time to deliver.

$x$

45. Better Back/GLA:D Back is compatible with daily practice.

X

$\mathrm{x}$

$\mathrm{x}$

$\mathrm{x}$

$x \quad$ SWE/DK

46. Better Back/GLA:D Back is simple to deliver.

$x$

$\mathrm{x}$

$\mathrm{x}$

x SWE/DK

10. Sociopolitical context
47. Government and local authorities provide sufficient support to interventions such as Better Back/GLA:D Back.

X 
48. Insurance companies provide sufficient support to

$\mathrm{X}$ interventions such as Better Back/GLA:D Back.

49. Primary Health Care is sufficiently oriented towards

$\mathrm{x}$

$x$

DK delivery of Better Back/GLA:D Back.

11. Organisation
50. In the organization I work, all necessary resources are available to deliver Better Back/GLA:D Back. $x$

$x$

$x$

$\mathrm{x}$

$\mathrm{x}$

SWE/DK
51. I can count on support from the management of the organization I work in, when things get tough programme. $x$

$\mathrm{x}$

x SWE/DK

52. The management of the organization I work in is willing to listen to my problems with delivering Better Back/GLA:D Back following the programme. 
helpful with delivering Better Back/GLA:D Back following the

programme.

13. Innovation strategy
56. [Implementing organization] provides professionals with training to deliver Better Back/GLA:D Back. $\mathrm{x}$

57. [Implementing organization] provides the possibility to $\mathrm{x}$ $x$ experience delivering Better Back/GLA:D Back before professionals need to commit to it. 
59. [Implementing organization] provides assistance to professionals with delivering Better Back/GLA:D Back. meetings for professionals.

61. [Implementing organization] provides sufficient financial reimbursement to professionals for Better Back/GLA:D Back delivery.

62. [Implementing organization] provides insights into results of Better Back/GLA:D Back. 
Back think I should deliver Better Back/GLA:D Back

following the programme.

65. Professionals with whom I deliver Better Back/GLA:D

Back deliver Better Back/GLA:D Back following the

programme.

66. Other professionals who work with Better Back/GLA:D

$x$

$x$

DK* Back deliver Better Back/GLA:D Back following the programme.

67. I can count on support from professionals with whom I

$x$

$x$

$\mathrm{X}$

$\mathrm{x}$

DK/SWE deliver Better Back/GLA:D Back when things get tough around delivering Better Back/GLA:D Back following the programme.

68. Professionals with whom I deliver Better Back/GLA:D 
69. Professionals with whom I deliver Better Back/GLA:D Back are helpful with delivering Better Back/GLA:D Back following the guideline.

15. Positive emotions
70. When I work with Better Back/GLA:D Back I feel optimistic.
71. When I work with Better Back/GLA:D Back I feel comfortable.
$\mathrm{X}$

72. When I work with Better Back/GLA:D Back I feel calm.

73. When I work with Better Back/GLA:D Back I feel relaxed.

74. When I work with Better Back/GLA:D Back I feel cheerful.

75. When I work with Better Back/GLA:D Back I feel elated. 
77. When I work with Better Back/GLA:D Back I feel pessimistic.

78. When I work with Better Back/GLA:D Back I feel depressed.

79. When I work with Better Back/GLA:D Back I feel agitated.

80. When I work with Better Back/GLA:D Back I feel sad.

81. When I work with Better Back/GLA:D Back I feel uncomfortable

$x$

$\mathrm{X}$

SWE/DK 
deliver Better Back/GLA:D Back following the programme.

84. I have a clear plan when I will deliver Better Back/GLA:D

Back/GLA:D Back following the programme when there is little time. 
18. Nature of 88. Delivering Better Back/GLA:D Back following the behavior

programme is something I do automatically.

89. Delivering Better Back/GLA:D Back following the

programme is something I do without having to

consciously remember.

90. Delivering Better Back/GLA:D Back following the programme is something I do without thinking.

91. Delivering Better Back/GLA:D Back following the programme is something I start doing before I realize I am doing it.

92. Delivering Better Back/GLA:D Back following the programme is something I seldom forget. 
* 40, 49, 59, 60, 62, 66, 71, 93: questions used only at follow-up - results are not reported in this study DK: Denmark, SWE: Sweden, CVI: Validity Index 
Table 3 DIBQ-t: Expectations to implementation: domains and items.

\begin{tabular}{|c|c|}
\hline DIBQ-t item-domain & Items \\
\hline DIBQ-t 1 - knowledge & I know how to deliver Better Back/GLA:D Back following the programme. \\
\hline DIBQ-t 2 - knowledge & Objectives of Better Back/GLA:D Back and my role in this are clearly defined for me. \\
\hline DIBQ-t 3 - skills & I have the skills to deliver Better Back/GLA:D Back. \\
\hline $\begin{array}{l}\text { DIBQ-t } 4 \text { - beliefs of } \\
\text { capability }\end{array}$ & I am confident that I can deliver Better Back/GLA:D Back. \\
\hline $\begin{array}{l}\text { DIBQ-t } 5 \text { - beliefs of } \\
\text { capability }\end{array}$ & I expect that, delivering Better Back/GLA:D Back is (very easy - very difficult). \\
\hline $\begin{array}{l}\text { DIBQ-t } 6 \text { - beliefs of } \\
\text { capability }\end{array}$ & I expect that, performing the intake is (very easy - very difficult). \\
\hline $\begin{array}{l}\text { DIBQ-t } 7 \text { - beliefs of } \\
\text { capability }\end{array}$ & I expect that, delivering the training program is (very easy - very difficult). \\
\hline $\begin{array}{l}\text { DIBQ-t } 8 \text { - beliefs of } \\
\text { capability }\end{array}$ & $\begin{array}{l}\text { I expect that, giving attention to participant's maintenance of physical activity behaviour outside } \\
\text { Better Back/GLA:D Back is (very easy - very difficult). }\end{array}$ \\
\hline $\begin{array}{l}\text { DIBQ-t } 9 \text { - beliefs of } \\
\text { capability }\end{array}$ & $\begin{array}{l}\text { I expect that, reporting about the Better Back/GLA:D Back to the referring professional is (very } \\
\text { easy - very difficult). }\end{array}$ \\
\hline $\begin{array}{l}\text { DIBQ-t } 10 \text { - beliefs of } \\
\text { consequences }\end{array}$ & I expect that, delivering Better Back/GLA:D Back is (not worthwhile at all - very worthwhile). \\
\hline $\begin{array}{l}\text { DIBQ-t } 11 \text { - beliefs of } \\
\text { consequences }\end{array}$ & If I deliver Better Back/GLA:D Back, Better Back/GLA:D Back will be most effective. \\
\hline $\begin{array}{l}\text { DIBQ-t } 12 \text { - beliefs of } \\
\text { consequences }\end{array}$ & $\begin{array}{l}\text { If I deliver Better Back/GLA:D Back, it will help participants to be able to cope better with their } \\
\text { back problems. }\end{array}$ \\
\hline $\begin{array}{l}\text { DIBQ-t } 13 \text { - beliefs of } \\
\text { consequences }\end{array}$ & I expect that, when I deliver Better Back/GLA:D Back, I get recognition from the work context. \\
\hline DIBQ-t 14 - intentions & I intend to deliver Better Back/GLA:D Back in the next three months. \\
\hline DIBQ-t 15 - innovation & It will be possible to tailor Better Back/GLA:D Back to participants' needs. \\
\hline DIBQ-t 16 - innovation & It will be possible to tailor Better Back/GLA:D Back to professionals' needs. \\
\hline DIBQ-t 17 - innovation & Better Back/GLA:D Back will be compatible with daily practice. \\
\hline DIBQ-t 18 - innovation & Better Back/GLA:D Back will be simple to deliver. \\
\hline $\begin{array}{l}\text { DIBQ-t } 19 \\
\text { organisation }\end{array}$ & $\begin{array}{l}\text { I expect that, in the organization I work, all necessary resources are available to deliver Better } \\
\text { Back/GLA:D Back. }\end{array}$ \\
\hline $\begin{array}{l}\text { DIBQ-t } 20 \\
\text { organisation }\end{array}$ & $\begin{array}{l}\text { I expect that, I can count on support from the management of the organization I work in, when } \\
\text { things get tough with the program. }\end{array}$ \\
\hline DIBQ-t 21 - patient & I expect that, participants of Better Back/GLA:D Back are motivated. \\
\hline DIBQ-t 22 - patient & I expect that, participants of Better Back/GLA:D Back are positive about Better Back/GLA:D Back. \\
\hline $\begin{array}{l}\text { DIBQ-t } 23-\text { social } \\
\text { influences }\end{array}$ & Most people who are important to me think that I should deliver Better Back/GLA:D Back. \\
\hline $\begin{array}{l}\text { DIBQ-t } 24-\text { social } \\
\text { influences }\end{array}$ & $\begin{array}{l}\text { Professionals with whom I deliver Better Back/GLA:D Back think I should deliver Better } \\
\text { Back/GLA:D Back. }\end{array}$ \\
\hline $\begin{array}{l}\text { DIBQ-t } 25-\text { social } \\
\text { influences }\end{array}$ & $\begin{array}{l}\text { I can count on support from professionals with whom I deliver Better Back/GLA:D Back when } \\
\text { things get tough around delivering Better Back/GLA:D Back. }\end{array}$ \\
\hline $\begin{array}{l}\text { DIBQ-t } 26 \text { - behavioral } \\
\text { regulation }\end{array}$ & I have a clear plan of how I will deliver Better Back/GLA:D Back. \\
\hline $\begin{array}{l}\text { DIBQ-t } 27 \text { - behavioral } \\
\text { regulation }\end{array}$ & I have a clear plan when I will deliver Better Back/GLA:D Back. \\
\hline $\begin{array}{l}\text { DIBQ-t } 28 \text { - behavioral } \\
\text { regulation }\end{array}$ & $\begin{array}{l}\text { I have a clear plan with regard to delivering Better Back/GLA:D Back when participants are } \mathrm{n} \\
\text { motivated. }\end{array}$ \\
\hline
\end{tabular}


Table 4. Results of the selected TDF domains for the DIBQ-t in relation to COM-B model categories. Categories of COM-B TDF domains (number of items in DIBQ-t)

Skills (1)

- Knowledge (2)

Capability $\quad$. Behavioral regulation (3)

Innovation (4)

Organisation (2)

Opportunity $\quad$ - Social influences (3)

Patients (2)

Intentions (1)

Motivation . Beliefs about capabilities (6)

Beliefs about consequences (4)

Table 5. Results from the construct validity testing after removal of 2 items

\begin{tabular}{lllllll}
\hline & $x^{2}$ & Df & p-value & CFI & TLI & RMSEA (90\% C.I.) \\
\hline Total model fit & 635.844 & 256 & 0,00 & 0.933 & 0.916 & $0.050(0.045-0.055)$ \\
\hline
\end{tabular}

CFI: Comparative Fit Index; TLI: Tucker-Lewis Index; RMSEA: Root Mean Square Error of Approximation; SRMR:

Standardized Root Mean Square Residual

Table 6. Correlation between the domains of the DIBQ-t

\begin{tabular}{lllllllllll}
\hline & $\begin{array}{l}\text { Knowled- } \\
\text { ge }\end{array}$ & Skills & $\begin{array}{l}\text { Capa- } \\
\text { bility }\end{array}$ & $\begin{array}{l}\text { Conse- } \\
\text { quences }\end{array}$ & Intention & $\begin{array}{l}\text { Innova- } \\
\text { tion }\end{array}$ & $\begin{array}{l}\text { Organi- } \\
\text { sation }\end{array}$ & $\begin{array}{l}\text { Patient } \\
\text { Social }\end{array}$ & $\begin{array}{l}\text { Beha- } \\
\text { vioural }\end{array}$ \\
\hline Knowledge & 1.00 & 0.69 & 0.52 & 0.55 & 0.22 & 0.51 & 0.39 & 0.35 & 0.26 & 0.35 \\
\hline Skills & 0.69 & 1.00 & 0.42 & 0.41 & 0.21 & 0.41 & 0.33 & 0.20 & 0.25 & 0.25 \\
\hline Capability & 0.52 & 0.42 & 1.00 & 0.38 & 0.19 & 0.64 & 0.41 & 0.41 & 0.22 & 0.50 \\
\hline Consequences & 0.41 & 0.41 & 0.38 & 1.00 & 0.38 & 0.74 & 0.48 & 0.51 & 0.59 & 0.36 \\
\hline Intention & 0.22 & 0.21 & 0.19 & 0.38 & 1.00 & 0.39 & 0.38 & 0.12 & 0.36 & 0.38 \\
\hline Innovation & 0.51 & 0.41 & 0.64 & 0.74 & 0.39 & 1.00 & 0.56 & 0.41 & 0.60 & 0.55 \\
\hline Organisation & 0.39 & 0.33 & 0.41 & 0.48 & 0.38 & 0.56 & 1.00 & 0.31 & 0.52 & 0.56 \\
\hline Patient & 0.35 & 0.20 & 0.41 & 0.51 & 0.12 & 0.31 & 0.24 & 1.00 & 0.26 & 0.26 \\
\hline Social & 0.26 & 0.25 & 0.22 & 0.59 & 0.36 & 0.60 & 0.52 & 0.26 & 1.00 & 0.36 \\
\hline Behavioural & 0.35 & 0.25 & 0.50 & 0.36 & 0.38 & 0.55 & 0.56 & 0.26 & 0.36 & 1.00
\end{tabular}

Figures 


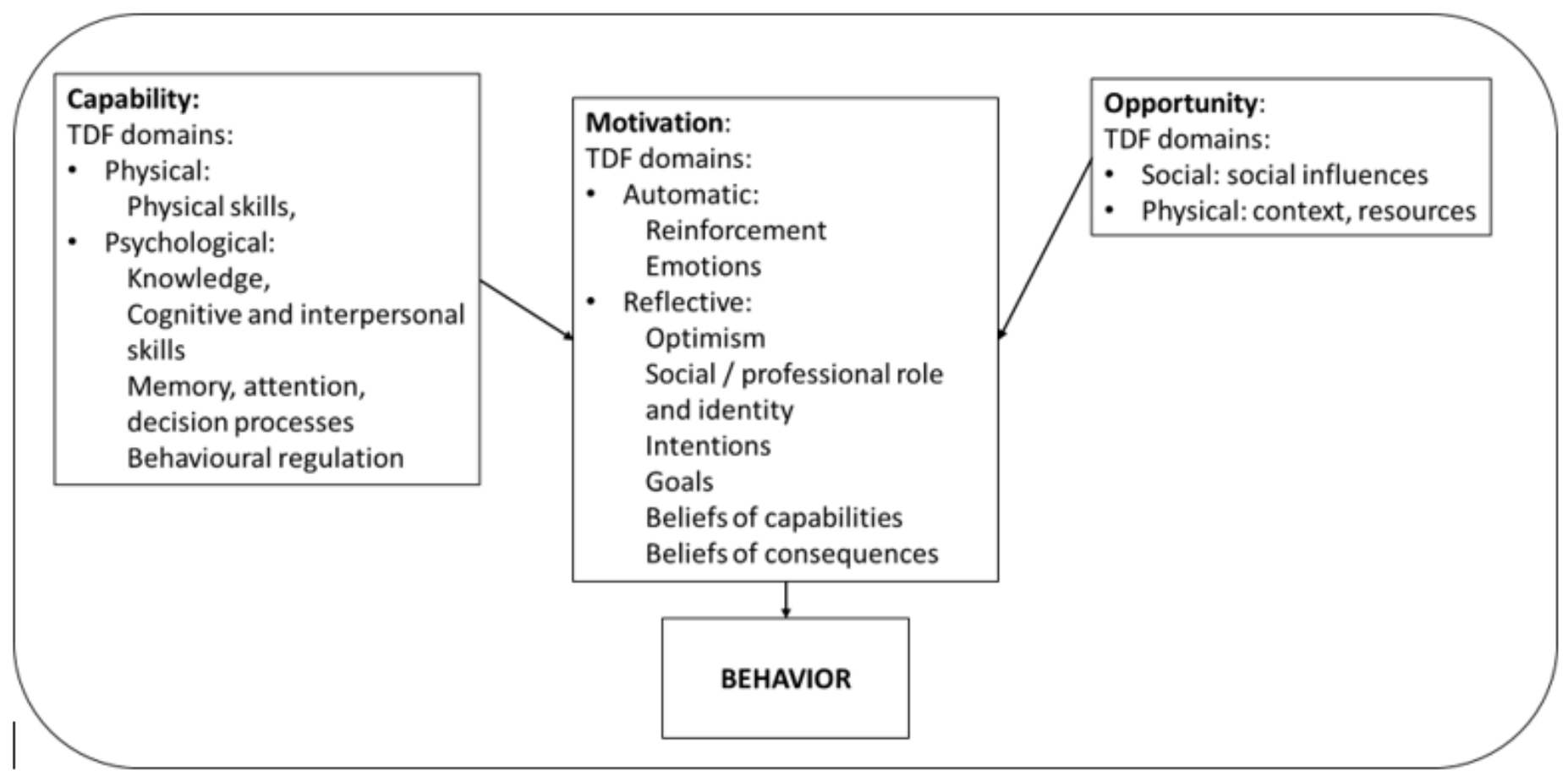

Figure 1

Linkage of the Theoretical Domains Framework domains to the COM-B model

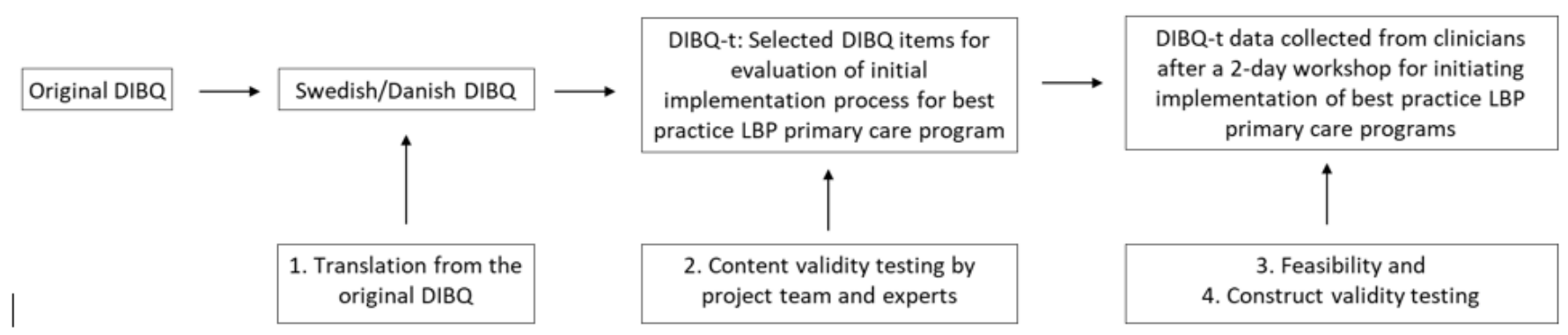

Figure 2

Process of development of a Swedish/Danish version into DIBQ-t. 


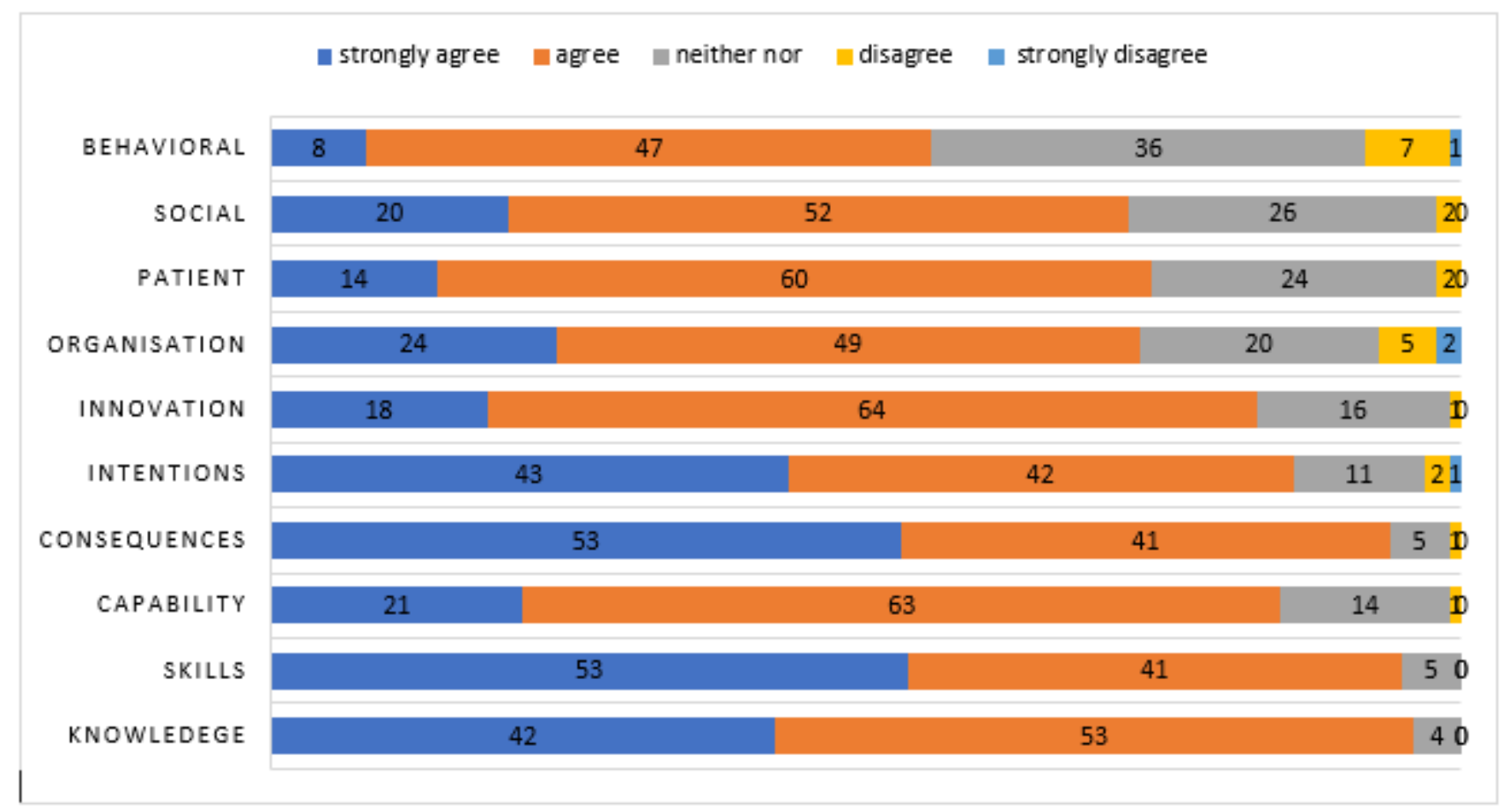

\section{Figure 3}

Distribution of responses of the DIBQ-t at domain-level for Sweden and Denmark combined in percentage on a 5-point Likert-scale. 
DIBQ 28 - BEHAVIORAL REGULATION DIBQ 27 - BEHAVIORAL REGULATION

DIBQ 26 - BEHAVIORAL REGULATION

DIBQ 25 - SOCIAL INFLUENCES DIBQ 24 - SOCIAL INFLUENCES

DIBQ 23 - SOCIAL INFLUENCES

DIBQ 22 - PATIENT DIBQ 21 - PATIENT

DIBQ 20 - ORGANISATION DIBQ 19 - ORGANISATION

DIBQ 18 - INNOVATION DIBQ 17 - INNOVATION DIBQ 16 - INNOVATION DIBQ 15 - INNOVATION DIBQ 14 - INTENTIONS

DIBQ 13 - CONSEQUENCES DIBQ 12 - CONSEQUENCES DIBQ 11 - CONSEQUENCES DIBQ 10 - CONSEQUENCES

DIBQ 9 - CAPABILITY DIBQ 8 - CAPABILITY DIBQ 7 - CAPABILITY DIBQ 6 - CAPABILITY DIBQ 5 - CAPABILITY DIBQ 4 - CAPABILITY

DIBQ 3 - SKILLS

DIBQ 2 - KNOWLEDGE DIBQ 1 - KNOWLEDGE

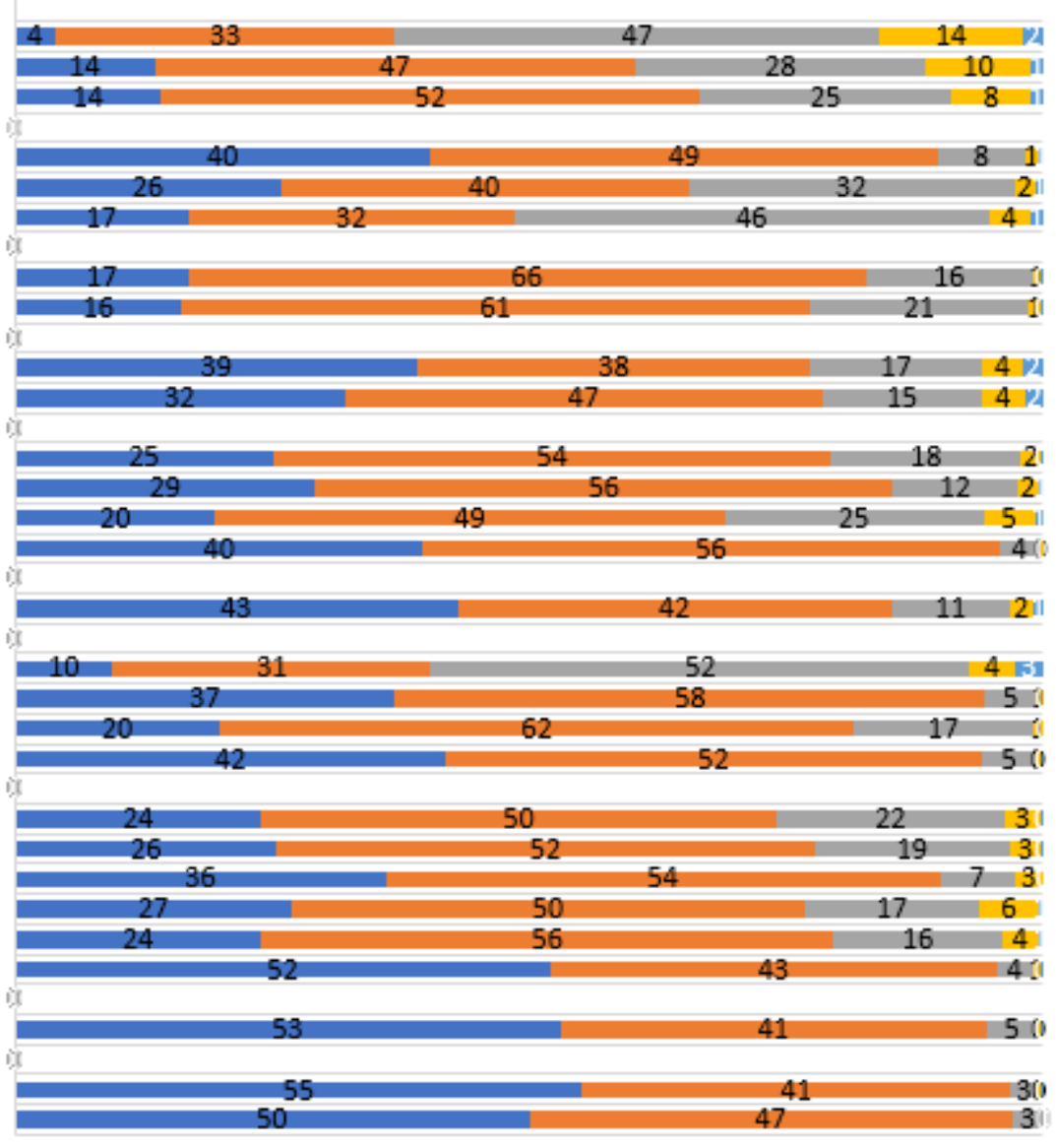

\section{Figure 4}

Distribution of responses to each item in the domains of DIBQ-t on a 5-point Likert-scale

\section{Supplementary Files}

This is a list of supplementary files associated with this preprint. Click to download.

- Additionalfilechecklist.docx

- Appendix1DIBQSwedish.docx

- Appendix2DIBQDanish.docx 